\title{
ANALISIS KEMAMPUAN KETERAMPILAN BERBICARA BAHASA INGGRIS TERHADAP KINERJA KARYAWAN PT BERRYS INTERNASIONAL JAKARTA
}

\author{
Oleh: \\ Iwan Budiarso \\ Dosen Prodi Teknik Informatika \\ Fakultas Teknik, Matematika, dan Ilmu Pengetahuan Alam \\ Universitas Indraprasta PGRI \\ Email: \\ budiarso.iwan@gmail.com
}

\begin{abstract}
ABSTRAK
Penelitian ini adalah sebuah analisis kemampuan berbicara bahasa Inggris pada para karyawan perusahaan. Tujuannya adalah ingin mengetahui sejauh mana persiapan kemampuan berbicara bahasa Inggris para karyawan perusahaan nasional swasta di Jakarta yang sudah beroperasi minimal dua tahun untuk menghadapi perdagangan bebas yang sudah berlangsung sejak awal tahun 2015 . Kemampuan berbahasa atau dalam hal ini berbicara bahasa Inggris speaking menjadi sebuah keharusan bagi pelaku bisnis di Indonesia supaya mampu bersaing dengan negara-negara Asia lainnya. Ketika para karyawannya telah memiliki keterampilan berbicara, ini merupakan aset besar yang akan mempengeruhi kinerja organisasi perusahaan tersebut, tidak hanya berkembang dalam skala nasional, akan tetapi mampu tumbuh dan sanggup bersaing dalam pasar Asia.
\end{abstract}

Kata Kunci: Kemampuan Berbicara, Kinerja, Karyawan

\section{A. PENDAHULUAN}

Indonesia telah memasuki era pasar bebas MEA (Masyarakat Ekonomi Asean) sejak awal tahun 2015 dan komunitas ekonomi ASEAN atau AEC (Asean Economy Community) telah menyepakati bahwa bahasa bisnis yang digunakan adalah bahasa Inggris. Ini menjadi catatan bagi seluruh warga Indonesia untuk berpikir keras bagaimana menyiapkan keterampilan berbahasa Inggris, dalam hal ini berbicara bahasa Inggris, agar mampu menghadapi pasar bebas tersebut. Kita dapat membayangkan, aktifitas dalam kehidupan kita menggunakan bahasa Inggris, petunjuk atau aturan dalam peraturan dagang menggunakan bahasa Inggris, apa yang terjadi jika kita tidak dapat berbahasa Inggris? Perlu kita renungkan dan sebagai pemicu semangat dan sekaligus menyadari betapa pentingnya bahasa Inggris di era MEA.

Hal ini tidak lain berlaku bagi perusahaan-perusahaan swasta nasional di Indonesia. Mereka wajib mempersiapkan para karyawannya menjadi mampu, mahir, mumpuni dalam berbahasa Inggris supaya dapat bersaing dalam mengikuti perkembangan yang tejadi di negara-negara Asia sekarang ini. 
Berangkat dari alasan di atas, peneliti melakukan penelitian kepada salah satu perusahaan di Jakarta yang telah beroperasi lebih dari dua tahun berdiri. Peneliti ingin mengetahui sejauh mana persiapan perusahaan tersebut bersaing dalam pasar bebas saat ini dan di masa yang akan datang.

Peneliti mendapatkan kesempatan untuk melakukan penelitian di perusahaan swasta nasional yang berlokasi di Jakarta dan telah beroperasi sejak awal tahun 2012. Perusahaan ini bergerak di bidang perdagangan alat-alat kesehatan menyuplai alat-alat kesehatan ke seluruh rumah sakit di Jakarta dan beberapa rumah sakit besar di luar Jawa. Awal pembicaraan dengan pemilik perusahaan, peneliti berdiskusi bagaimana langkah kedepan tentang perusahaan yang dipimpinnya dalam menghadapi pasar bebas ASEAN dan kiat-kiat apa saja ketika nantinya ada pesaing dari Negara-negara lain yang memasarkan produk yang sama dan di rumah sakit yang sama. Pimpinan perusahaan menyadari betapa pentingnya bahasa Inggris berperan dalam persaingan tersebut. Atas dasar itulah, perusahaan memberi ijin kepada peneliti untuk melakukan penelitian guna mengukur kemampuan berbicara bahasa Inggris karyawan.

\section{B. KAJIAN PUSTAKA}

\section{Keterampilan Berbicara (Speaking Skills)}

Menurut Kamus Besar Bahasa Indonesia (2003) berbicara adalah suatu kegiatan berkata, bercakap, berbahasa, melahirkan pendapat dengan perkataan atau lisan dan sebagainya. Tarigan (2005) menjelaskan bahwa berbicara adalah kemampuan mengucapkan bunyi-bunyi artikulasi atau kata-kata untuk mengekpresikan, menyatakan serta menyampaikan pikiran, gagasan dan perasaan. Berbicara merupakan suatu sistem tanda-tanda yang dapat didengar (audible) dan yang kelihatan (visible) yang memanfaatkan sejumlah otot dan jaringan otot tubuh manusia demi maksud dan tujuan gagasan-gagasan atau ide yang dikombinasikan.

Menurut Tarigan (2005), berbicara dapat digunakan untuk berbagai keperluan antara lain:

1. Memberitahukan, melaporkan (to inform);

2. Menjamu, menghibur (to entertaint);

3. Membujuk, mengajak, mendesak, meyakinkan (to persuade).

Menurut Dipodjojo (1984) berbicara merupakan suatu kegiatan yang mengikut sertakan sebagian besar anggota tubuh manusia. Berbicara atau disebut komukikasi lisan merupakan suatu kegiatan perseorangan guna menyampaikan pesan secara lisan kepada pendengar atau audience.

Dalam berbicara yang diperhatikan tidak hanya berarti berbicara dengan lancar, tetapi juga harus memperhatikan cara penyampaian yang dapat juga dilakukan dengan cara yang singkat, padat namun jelas informasi yang disampaikan dan memiliki cara yang mengesankan. Mengesankan dalam hal ini berarti dapat menarik perhatian pendengar misalnya diselingi dengan cara mengucapkannya atau gerakan yang kreatif. Berdasarkan pendapat yang ada, maka dapat disimpulkan bahwa berbicara adalah suatu proses komunikasi antara seseorang dengan orang lain atau sekelompok orang untuk mengungkapkan suatu pikiran, perasaan ataupun gagasan dengan lisan guna memberikan suatu 
informasi. Menurut jumlah orang yang berbicara ada yang disebut sebagai monolog dan ada dialog.

\section{Pengertian Kinerja (Performance)}

Kinerja merupakan gambaran mengenai sejauh mana keberhasilan atau kegagalan organisasi dalam menjalankan tugas dan fungsi pokoknya dalam rangka mewujudkan sasaran, tujuan, visi, dan misinya. Dengan kata lain, kinerja merupakan prestasi yang dapat dicapai oleh organisasi dalam periode tertentu.

Menurut Mulyadi (2001) kinerja adalah keberhasilan personil, tim, atau unit organisasi dalam mewujudkan sasaran strategik yang telah ditetapkan sebelumnya dengan perilaku yang diharapkan. Kinerja perusahaan merupakan sesuatu yang dihasilkan oleh perusahaan dalam periode tertentu dengan mengacu pada standar yang ditetapkan. Kinerja perusahaan hendaknya merupakan hasil yang dapat diukur dan menggambarkan kondisi empirik suatu perusahaan dari berbagai ukuran yang disepakati. Jadi, dapat disimpulkan bahwa kinerja adalah kemampuan, usaha, dan kesempatan personil, tim, atau unit organisasi dalam melaksanakan tugasnya untuk mewujudkan sasaran strategik yang telah ditetapkan.

Kedua teori di atas sebagai dasar peneliti melakukan penelitian. Fokusnya adalah kemampuan berbicara bahasa Inggris dan kinerja atau goal atau cakupan usaha yang dihasilkan dalam melakukan bisnis.

\section{METODE PENELITIAN}

Metode yang digunakan dalam penelitian ini adalah metode deskriptif dengan pendekatan kualitatif. Sugiyono (2009) mendefinisikan bahwa "Metode deskriptif adalah metode yang digunakan untuk menggambarkan atau menganalisis suatu hasil penelitian tetapi tidak digunakan untuk membuat kesimpulan yang lebih luas". Sedangkan penelitian deskriptif yang dikemukakan oleh Kuncoro (2003) adalah sebagai berikut, "Penelitian deskriptif meliputi kegiatan pengumpulan data untuk menjawab pertanyaan mengenai status terakhir dari subyek penelitian. Tipe yang paling umum dari penelitian deskriptif meliputi penilaian terhadap individu, organisasi atau keadaan tertentu".

Berdasarkan penjelasan diatas, maka metode yang digunakan dalam penelitian ini adalah metode deskriptif dengan pendekatan kualitatif, yaitu hasil penelitian yang kemudian diolah dan dianalisis untuk diambil kesimpulannya sehingga menghasilkan kesimpulan yang akan memperjelas gambaran mengenai objek yang diteliti.

\section{HASIL DAN PEMBAHASAN}

PT Berrys Internasional adalah perusahaan swasta di Jakarta yang bergerak dibidang pengadaan barang berupa alat-alat kesehatan yang telah beroperasi sejak awal tahun 2012 dan memiliki karyawan sebanyak 12 orang, termasuk 3 orang direksi. Jam operasional kantor selama 8 jam, masuk kantor pukul 08.00 dan keluar kantor pukul 17.00 setiap harinya, kecuali jam kerja di hari Sabtu hanya setengah hari dan hari Minggu libur. 
Peneliti mengambil data penelitian pada bulan Mei 2016 dengan cara pengambilan data langsung di PT Berrys Internasional Jakarta sebagai objek penelitian. Adapun cara yang dilakukan adalah dengan wawancara (interview) dan meminta setiap karyawan melakukan presentasi menggunakan bahasa Inggris menjelaskan produk yang mereka jual.

Tabel. 1

Pengurus dan Karyawan Perusahaan

\begin{tabular}{llccl}
\hline NO & NAMA & UMUR (TAHUN) & PENDIDIKAN & \multicolumn{1}{c}{ JABATAN } \\
\hline 1. & RIP & 33 & D3 & Direktur Utama \\
2. & MA & 36 & S1 & Direktur \\
3. & AN & 35 & D3 & Komisaris \\
4. & BP & 40 & S1 & Marketing 1 (co.) \\
5. & HE & 40 & D1 & Marketing 2 \\
6. & DA & 33 & D3 & Marketing 3 \\
7. & AH & 45 & D3 & Keuangan 1 \\
8. & KS & 35 & D3 & Keuangan 2 \\
9. & DN & 38 & D3 & Operasional/General Affair \\
10. & ID & 33 & D1 & HRD \\
11. & IMA & 29 & D3 & Administrasi \\
12. & DK & 27 & SMA & Receptionist \\
\hline
\end{tabular}

Dari data di atas yang menempuh pendidikan strata satu sebanyak 2 orang. Rata-rata dari mereka adalah lulusan dari diploma, diploma satu 1 sebanyak orang dan diploma tiga sebanyak 6 orang.

Aspek yang dinilai oleh peneliti tentang kemampuan atau keterampilan berbicara (speaking skills) adalah dari segi pengucapan, tata bahasa, kosakata, kelancaran, dan pemahaman. Skor yang diberikan mulai dari skor satu sampai dengan skor lima, seperti peneliti uraikan di bawah ini:

1. Pengucapan

Karyawan yang mengalami masalah dalam pengucapan yang serius sehingga tidak bisa dipahami, maka diberi skor satu. Karyawan yang pengucapannya sulit dipahami karena sering mengulangi ucapan yang sama, maka diberi skor dua. Karyawan yang memiliki pengucapan yang membuat pendengar harus berkonsentrasi penuh dan kadang-kadang ada kesalahpahaman, maka diberi skor tiga. Mereka yang memiliki pengucapan yang mudah dipahami meski memakai aksen bukan penutur asli melainkan aksen tertentu, maka diberi skor empat. Adapun skor tertinggi, yaitu skor lima diberikan kepada karyawan yang memiliki pengucapan yang mudah dipahami dan memiliki aksen penutur asli.

2. Tata Bahasa

Karyawan yang memiliki tata bahasa yang begitu parah sehingga sulit dipahami, ia mendapat skor satu. Karyawan yang banyak mengalami kesalahan tata bahasa dan menghambat makna dan sering menata ulang kalimat, maka diberikan skor dua. Karyawan yang sering membuat 
kesalahan tata bahasa yang mempengaruhi makna, maka diberi skor tiga. Karyawan yang kadang-kadang membuat kesalahan tata bahasa tetapi tidak mempengaruhi makna, maka diberi skor empat. Mereka yang tidak ada atau sedikit kesalahan tata bahasa, maka ia berhak mendapat skor lima, skor tertinggi.

3. Kosakata

Karyawan yang memiliki kosakata terbatas sehingga percakapan tidak mungkin terjadi, maka ia mendapatkan skor satu. Skor dua diberikan kepada karyawan yang menggunakan kosakata secara salah dan kosakata terbatas sehingga sulit dipahami. Karyawan yang sering menggunakan kosakata yang tidak tepat, percakapan menjadi terbatas karena keterbatasan kosakata, maka diberi skor tiga. Karyawan yang kadang-kadang menggunakan kosakat yang tidak tepat, maka diberi skor empat. Karyawan yang menggunakan kosakata dan ungkapan penutur asli, diberi skor lima.

\section{Kelancaran}

Karyawan yang berbicara terputus-putus dan terhenti sehingga percakapan tidak mungkin terjadi, maka mendapat skor satu. Karyawan yang sering ragu-ragu dan terhenti karena keterbatasan bahasa mendapat skor dua. Karyawan yang kelancaran pengucapannya banyak terganggu oleh masalah bahasa mendapat skor tiga. Kelancaran tampak sedikit terganggu oleh masalah bahasa mendapat skor empat dan kelancarannya seperti penutur asli mendapat skor tertinggi.

5. Pemahaman

Karyawan yang tidak bisa memahami walaupun percakapan sederhana mendapat skor satu. Karyawan yang susah mengikuti apa yang dikatakan mendapat skor dua. Karyawan yang memahami sebagaian besar apa yang dikatakan bila bicara agak diperlambat mendapat poin tiga. Karyawan yang memahami hampir semuanya, walau pun ada pengulangan pada bagian tertentu, maka mendapat skor empat. Skor lima diberikan kepada mereka yang dapat memahami semua tanpa mengalami kesulitan, lancar.

Dibawah ini adalah hasil penilaian dari lima aspek di atas menggunakan tabel agar lebih jelas dan mudah untuk dipahami. 
Tabel 2.

Penilaian Speaking

\begin{tabular}{|c|c|c|c|}
\hline \multirow[t]{4}{*}{ NO } & \multicolumn{3}{|r|}{ PENILAIAN SPEAKING } \\
\hline & ASPEK & SKOR & $\begin{array}{ll}\text { KETERANGAN } \\
\end{array}$ \\
\hline & & 5 & $\square$ Mudah dipahami dan memiliki aksen penutur asli \\
\hline & & 4 & $\square$ Mudah dipahami meskipun dengan aksen tertentu \\
\hline \multirow[t]{5}{*}{1} & Pengucapan & 3 & $\begin{array}{l}\square \text { Ada masalah pengucapan yang membuat pendengar harus } \\
\text { konsentrasi penuh dan kadang-kadang ada kesalahpahaman }\end{array}$ \\
\hline & & 2 & $\begin{array}{l}\square \text { Sulit dipahami karena ada masalah pengucapan, sering diminta } \\
\text { mengulang }\end{array}$ \\
\hline & & 1 & $\square$ Masalah pengucapan serius sehingga tidak bisa dipahami \\
\hline & & 5 & $\square$ Tidak ada atau sedikit kesalahan tata bahasa \\
\hline & & 4 & $\begin{array}{l}\square \text { Kadang-kadang membuat kesalahan tata bahasa tetapi tidak } \\
\text { mempengaruhi makna }\end{array}$ \\
\hline \multirow[t]{6}{*}{2} & Tata Bahasa & 3 & $\begin{array}{l}\square \text { Sering membuat kesalahan tata bahasa yang mempengaruhi } \\
\text { makna }\end{array}$ \\
\hline & & 2 & $\begin{array}{l}\square \text { Banyak kesalahan tata bahasa yang menghambat makna dan } \\
\text { sering menata ulang kalimat }\end{array}$ \\
\hline & & 1 & $\square$ Kesalahan tata bahasa begitu parah sehingga sulit dipahami \\
\hline & & 5 & $\square$ Menggunakan kosa kata dan ungkapan seperti penutur asli \\
\hline & & 4 & $\square$ Kadang-kadang menggunakan kosa kata yang tidak tepat \\
\hline & Koga Kat? & 3 & $\begin{array}{l}\square \text { Sering menggunakan kosa kata yang tidak tepat, percakapan } \\
\text { menjadi terbatas karena keterbatasan kosa kata }\end{array}$ \\
\hline \multirow{4}{*}{3} & Kosa Kata & 2 & $\begin{array}{l}\square \text { Menggunakan kosa kata secara salah dan kosa kata terbatas } \\
\text { sehingga sulit dipahami }\end{array}$ \\
\hline & & 1 & $\begin{array}{l}\square \text { Kosa kata sangat terbatas sehingga percakapan tidak mungkin } \\
\text { terjadi }\end{array}$ \\
\hline & & 5 & $\square$ Lancar seperti penutur asli \\
\hline & & 4 & $\square$ Kelancaran tampak sedikit terganggu oleh masalah bahasa \\
\hline \multirow{5}{*}{4} & & 3 & $\square$ Kelancaran agak banyak terganggu oleh masalah bahasa \\
\hline & Kelancaran & 2 & $\square$ Sering ragu-ragu dan terhenti karena keterbatasan bahasa \\
\hline & & 1 & $\begin{array}{l}\square \text { Bicara terputus-putus dan terhenti sehingga percakapan tidak } \\
\text { mungkin terjadi }\end{array}$ \\
\hline & & 5 & $\square$ Memahami semua tanpa mengalami kesulitan \\
\hline & & & $\begin{array}{l}\text { Memahami 6hampir semuanya, walau ada pengulangan pada } \\
\text { bagian tertentu }\end{array}$ \\
\hline \multirow[t]{3}{*}{5} & Pemahaman & & $\begin{array}{l}\square \text { Memahami sebagian besar apa yang dikatakan bila bicara agak } \\
\text { diperlambat walau ada pengulangan }\end{array}$ \\
\hline & & 2 & $\square$ Susah mengikuti apa yang dikatakan. \\
\hline & & 1 & $\square$ Tidak bisa memahami walaupun percakapan sederhana \\
\hline
\end{tabular}

Selama satu bulan, selama bulan Mei 2016, peneliti mengambil penilaian dari setiap karyawan sehingga menghasilkan keterangan nilai sebagai berikut: 
Tabel 3.

Hasil Penilaian

\begin{tabular}{llccccc}
\hline NO & NAMA & PENGUCAPAN & $\begin{array}{c}\text { TATA } \\
\text { BAHASA }\end{array}$ & KOSAKATA & KELANCARAN & PEMAHAMAN \\
\hline 1. & RIP & 3 & 3 & 3 & 3 & 3 \\
2. & MA & 4 & 4 & 4 & 4 & 4 \\
3. & AN & 3 & 3 & 3 & 3 & 3 \\
4. & BP & 4 & 5 & 4 & 4 & 4 \\
5. & HE & 3 & 3 & 3 & 2 & 3 \\
6. & DA & 3 & 3 & 3 & 2 & 2 \\
7. & AH & 2 & 2 & 2 & 2 & 2 \\
8. & KS & 3 & 2 & 2 & 2 & 2 \\
9. & PM & 3 & 3 & 2 & 2 & 2 \\
10. & ID & 2 & 2 & 2 & 2 & 2 \\
11. & IMA & 2 & 2 & 2 & 2 & 2 \\
12. & DK & 2 & 2 & 2 & & 2 \\
\hline
\end{tabular}

Data nilai di atas menunjukkan kemampuan karyawan PT Berrys Internasional dalam menguasai keterampilan berbicara (speaking skills). Dua orang yang memiliki pengucapan yang mudah dipahami meskipun dengan aksen daerah, Sunda dan Ambon. Ada enam orang yang memiliki masalah dalam pengucapan sehingga pendengar harus benar-benar berkonsentrasi penuh dan kadang-kadang ada kesalahpahaman. Selebihnya yaitu ada empat orang yang mengalami kesulitan dalam pengucapan, terlihat dari sering diulangnya ucapan yang sudah disebutkan sebelumnya.

Berkenaan dengan tata bahasa, hanya ada satu orang tidak mengalami kesulitan dalam tata bahasa dan satu orang lagi kadang-kadang membuat kesalahan tata bahasa namun tidak mengubah arti atau makna. Ada lima orang yang sering mengalami kesalahan tata bahasa yang mempengaruhi makna dan lima orang lagi yang melakukan banyak kesalahan tata bahasa yang menghambat makna dan sering menata ulang kalimat.

Dalam penguasaan kosa kata, ada dua orang yang mendapat nilai empat, ini artinya mereka kadang-kadang menggunakan kosakata yang tidak tepat dan dua orang lagi sering menggunakan kosakata yang tidak tepat sehingga percakapan menjadi terbatas karena keterbatasan kosa kata. Selebihnya, ada enam orang yang menggunakan kosakata secara salah dan kosakata terbatas sehingga sulit dipahami.

Berbicara bahasa Inggris dengan lancar ada dua orang tapi agak sedikit terganggu dengan bahasa dan dua orang lagi banyak terganggu dengan bahasa. Selebihnya sering ragu-ragu dan terhenti karena keterbatasan bahasa.

Aspek terakhir yang dinilai adalah aspek pemahaman apa yang mereka sampaikan. Dua orang yang mendapat skor empat yang artinya memahami semua apa yang mereka bicarakan. Tiga orang yang mendapatkan skor tiga karena mereka memahami sebagian besar apa yang diucapkan namun bicaranya agak lambat dan ada pengulangan. Dan enam orang diantaranya susah mengikuti apa yang dikatakan. 


\section{E. SIMPULAN}

Dari data penelitian yang didapat, peneliti dapat menyimpulkan bahwa dari dua belas orang karyawan PT Berrys Internasional yang diwawancarai dan peneliti meminta mereka untuk mempresentasikan menggunakan bahasa Inggris tentang barang yang mereka jual, ternyata hanya ada dua orang yang peneliti anggap cukup mengusai English speaking skills. Hal ini menunjukkan bahwa kemampuan berbicara bahasa Inggris PT Berrys Internasional masih minim dan ini tentu sangat berpengaruh terhadap kinerja karyawannya dalam memasarkan barang-barang alat kesehatan yang menjadi produk dagang mereka. Terbukti selama kurang lebih 4 tahun sejak perusahaan ini berdiri belum juga melebarkan jangkauan bisnisnya ke kancah pasar Asia dan masih lingkup Ibu Kota Jakarta dan kota-kota besar di luar Jawa. 


\section{DAFTAR PUSTAKA}

Asdi S. D. (1984). Kemunikasi Lisan. Yogyakarta: P.D. Lukman.

Alwi, Hasan. (2003). Kamus Besar Bahasa Indonesia. Jakarta: Balaik Pustaka.

Mulyadi. (2001). Sistem Perencanaan dan Pengendalian Manajemen. Edisi kedua. Jakarta: Salemba Empat.

Tarigan, Henry Guntur. (2005). Pengajaran Pragmatik. Bandung: Angkasa.

Widiyarto, Sigit dan Sri Sulastri. (2015). Peranan Kemampuan Komunikasi Bahasa Inggris Guna Peningkatan Daya Saing SDM Menghadapi MEA. Journal of Applied Business and Economic Vol. 2 No. 2 ISSN 2356-4849.

Wuryanto, Agus. (2011). Rubrik peneliaian Bahasa Inggris. http://aguswuryanto.wordpress.com/2011/09/13/. Diakses 02 April 2016 